\title{
ANALISIS REGRESI PELATIHAN TERHADAP KINERJA PENYIDIK PEMBANTU PADA POLRES PESAWARAN
}

\author{
Zalalia Alfiolieta ${ }^{(1)}$, Abdul Naser ${ }^{(2)}$, Maria Elina ${ }^{(3)}$ \\ Fakultas Ekonomi Universitas Sang Bumi Ruwa Jurai \\ zalalia.alfiolieta@gmail.com,abdul.naser@fe.saburai.ac.id,maria.elina@fe.saburai.ac.id
}

\begin{abstract}
Abstrak. Pelatihan dan pengembangan sering kita dengar dalam dunia kerja di perusahaan, organisasi, lembaga, atau bahkan dalam institusi penegak hukum. Hal ini dapat diasumsikan bahwa pelatihan dan pengembangan sangat penting bagi tenaga kerja untuk bekerja lebih menguasai dan lebih baik terhadap pekerjaan yang dijabat atau akan dijabat kedepan. Tujuan dari penelitian ini adalah Adapun yang menjadi tujuan dari penelitian ini adalah untuk mengetahui berapa besar pengaruh pelatihan terhadap kinerja penyidik pembantu pada Polres Pesawaran Lampung Selatan. Penelitian ini menggunakan metode analisis kualitatif dan kuantitatif. Pengumpulan data penelitian menggunakan teknik populasi dari seluruh penyidik pembantu pada Polres Pesawaran berjumlah 25 orang. Berdasarkan hasil analisis kuantitatif, persentase sumbangan perubahan variabel independen pelatihan $(\mathrm{X})$ terhadap variabel dependen kinerja $(\mathrm{Y})$ sebesar $82,3 \%$ dan sisanya dipengaruhi faktor lain. Uji hipotesis parsial melalui uji t test diperoleh nilai $t$ hitung pelatihan terhadap kinerja sebesar 10,355 dan $t_{\text {hitung }}=10,355>t_{\text {tabel }} 1,714$. Persamaan regresi antara pelatihan dan kinerja pada Polres Pesawaran adalah sebesar $\mathrm{Y}=-1,538+0,948 \mathrm{X}+\mathrm{e}$, yang menunjukkan setiap kenaikan satu satuan dari variabel pelatihan akan diikuti oleh naiknya variabel kinerja pada Polres Pesawaran sebesar 0,948 satuan.
\end{abstract}

Kata kunci: Analisis, Kinerja, Pelatihan, Regresi.

\section{PENDAHULUAN}

Sumber daya manusia adalah faktor yang paling menentukan dalam pencapaian tujuan perusahaan. Karena sumber daya manusia termasuk unsur dari kekuatan daya saing bangsa, untuk itu sumber daya manusia dituntut menjadi unggul dan professional dalam kerjanya demi kemajuan dan pencapaian tujuan perusahaan di Indonesia khususnya agar bisa bersaing dalam era globalisasi ini.

Apa jadinya jika menerima pegawai penyidik pembantu tanpa mengadakan pelatihan (training). Bisa jadi penyidik pembantu tersebut bingung entah bagaimana untuk mengawali pekerjaannya. Pelatihan sangat dibutuhkan untuk penyidik pembantu baru atau pun penyidik pembantu yang naik jabatan, karena pada dasarnya penyidik pembantu tersebut memasuki lingkungan kerja yang lebih baik.
Pelatihan dan pengembangan sering kita dengar dalam dunia kerja di perusahaan, organisasi, lembaga, atau bahkan dalam institusi penegak hukum. Hal ini dapat diasumsikan bahwa pelatihan dan pengembangan sangat penting bagi tenaga kerja untuk bekerja lebih menguasai dan lebih baik terhadap pekerjaan yang dijabat atau akan dijabat kedepan. Tidak terlalu jauh dalam institusi penegak hukum, pelatihan dan pengembangan sering dilakukan sebagai upaya meningkatkan kinerja para tenaga kepolisian yang dianggap belum mampu untuk mengemban pekerjaannya.

Secara deskripsi tertentu potensi para tenaga kepolisian mungkin sudah memenuhi syarat administarasi pada pekerjaannya, tapi secara aktual para tenaga kepolisian harus mengikuti atau mengimbangi perkembangan dunia kespolisian sesuai dengan tugas yang dijabat atau yang akan dijabatnya. Hal ini 
yang mendorong pihak institusi kepolisian untuk memfasilitasi pelatihan dan pengembangan karir para tenaga kesehatan guna mendapatkan hasil kinerja yang baik, efektif dan efisien.

Salah satu fungsi manajemen surmber daya manusia adalah training and development artinya bahwa untuk mendapatkan tenaga kepolisian yang bersumber daya manusia yang baik dan tepat sangat perlu pelatihan dan pengembangan. Hal ini sebagai upaya untuk mempersiapkan para tenaga kepolisian untuk menghadapi tugas pekerjaan jabatan yang dianggap belum menguasainya.

Management thought yang dikernukakan Taylor, bahwa tenaga kerja membutuhkan latihan kerja yang tepat. Teori ini sangat tepat untuk rnenghindari kemungkinan terburuk dalam kemampuan dan tanggung jawab bekerja, sehingga dalam menyelesaikan tugas jabatan lebih efektif dan efisien sesuai dengan aturan yang telah ditetapkan. Dalam institusi kepolisian biasanya para tenaga kerja yang akan menduduki jabatan baru yang tidak didukung dengan pendidikannya atau belum mampu melaksanakan tugasnya, biasanya upaya yang ditempuh adalah dengan melakukan pelatihan dan pengembangan karir. Dengan melalui pelatihan dan pengembangan, tenaga kerja akan mampu mengerjakan, meningkatkan, mengembangkan pekerjaannya.

Polres Pesawaran Lampung sebagai organisasi/institusi polri penegak hukum yang bertugas dalam menajaga keamanan dan ketertiban masyarakat dan memiliki anggota disetiap bidang khususnya menyelenggarakan penyelidikan bagi para tim penyidik pembangtu ini membutuhkan pelatihan untuk melatih para penyidik pembantu agar dapat melaksanakan tugas dengan baik. Menyadari pentingnya pelatihan diperlukan adanya koordinasi yang baik dari setiap bagian.
Koordinasi penting dalam organisasi, karena didalamnya terdapat kegiatan yang berlainan dan dilakukan banyak orang, sehingga perlu adanya koordinasi yang baik agar tidak terjadi kesimpangan siuran kegiatan dan dapat ditujukan kepada titik arah pencapaian tujuan dengan efisien.

pelatihan yang telah diikuti oleh seluruh anggota tim penyidik pembantu Polres Pesawaran berjumlah 100. Dari seluruh anggota tim penyidik pembantu sebanyak 25 orang, semuanya pernah mengikuti pelatihan minimal 1 kali. Berkas yang pernah ditangani pun sebanyak 194 tetapi para penyidik pembantu yang telah mengikuti pelatihan pada Polres Pesawaran belum sepenuhnya menerapkan materi yang diajarkan pada saat pelatihan pada pekerjaannya dan evaluasi pelatihan yang dilaksanakan belum sepenuhnya terlaksana. Evaluasi pelatihan sangatlah penting bagi individu ataupun organisasi, karena tujuan evaluasi ini yaitu untuk mengetahui sejauh mana kegiatan pelatihan telah mencapai tujuan.

Menurut (Simanjuntak, 2011) kinerja adalah tingkat pencapaian hasil atas pelaksanaan tugas tertentu. Kinerja organisasi adalah tingkat pencapaian hasil dalam rangka mewujudkan tujuan organisasi. Manajemen kinerja adalah keseluruhan kegiatan yang dilakukan untuk meningkatkan kinerja organisasi, termasuk kinerja masing-masing individu dan kelompok kerja di organisasi tersebut. Kinerja individu, kinerja kelompok dan kinerja organisasi, dipengaruhi oleh banyak faktor intern dan ekstern organisasi.

Para penyidik pembantu yang telah mengikuti pelatihan pada Polres Pesawaran belum menerapkan materi yang diajarkan pada saat pelatihan pada pekerjaannya dan evaluasi pelatihan yang dilaksanakan belum sepenuhnya terlaksana. Evaluasi pelatihan sangatlah penting bagi individu ataupun organisasi, karena tujuan evaluasi ini yaitu untuk mengetahui sejauh mana kegiatan 
pelatihan telah mencapai tujuan. Selain evaluasi, anggaran dana yang disediakan dianggap belum mencukupi untuk melakukan pengembangan aparatur khususnya mengenai pelatihan sehingga dalam pelaksanaannya selalu mengalami keterlambatan.

Dengan demikian suatu pengetahuan dan pemahaman secara komprehensif terhadap faktor-faktor penentu yang dapat meningkatkan kinerja penyidik pembantu haruslah diidentifikasi secara lebih dini. Melalui penelitian ini peneliti ingin mengkaji dengan judul: "Analisis Regresi Pelatihan terhadap Kinerja Penyidik Pembantu pada Polres Pesawaran Lampung."

\section{KAJIAN TEORI}

\section{Pengertian Pelatihan}

Menurut (Andrew E. Sikula, 1981 dalam (Mangkunegara, 2011) menyatakan bahwa pelatihan adalah suatu proses pendidikan jangka pendek yang mempergunakan prosedur sistematis dan terorganisir dimana pegawai non managerial. Menurut Intruksi Presiden No 15 tahun 1974 dalam (Sedarmayanti, 2013) menyatakan pelatihan adalah bagian dari pendidikan menyangkut proses belajar untuk memperoleh dan meningkatkan keterampilan diluar system pendidikan yang berlaku, dalam waktu yang relative singkat dan dengan metode yang lebih mengutamakan praktek dari pada teori.

Dari pengertian para ahli diatas tentang pelatihan, maka penulis merangkum bahwa pelatihan adalah pendidikan untuk mempelajari pengetahuan dan meningkatkan kemampuan teknis pegawai di dalam pekerjaannya yang sekarang atau pekerjaan yang akan dijabatnya segera dengan prosedur yang sistematis dalam jangka waktu yang singkat dan lebih mengutamakan praktek dari pada teori.

\section{Faktor-Faktor yang Mempengaruhi Pelatihan}

Faktor-faktor yang mempengaruhi pelatihan menurut (Marwansyah, 2014) antara lain :

1. Dukungan Manajemen puncak

Program pelatihan harus mendapatkan dukungan penuh dari menajemen puncak dalam sebuah organisasi. Dukungan ini harus bersifat konkret dan perlu dikomunikasikan kepada seluruh bagian organisasi. Selanjutnya dukungan ini harus diwujudkan dalam bentuk sumber daya yang memadai untuk melaksanakan pelatihan dan pengembangan sumber daya manusia.

2. Komitmen para spesialis dan generalis dalam pengelolaan SDM

Dibutuhkan komitmen yang kuat dan keterlibatan para manajer generalis dalam pengelolaan sumber daya manusia, dan terutama para manajer spesialis pelatihan dan pengembangan SDM.

3. Perkembangan teknologi

Kemajuan tekhnologi tidak saja memberikan dampak pada identifikasi kebutuhan pelatihan dan pengambangan tetapi juga terhadap pemilihan metode pelatihan dan pengembangan.

4. Kompleksitas organisasi

Kompleksitas organisasi, seorang pekerja yang sukses harus secara berkesinambungan meningkatkan atau memperbarui kompetensi mereka dan membangun sikap yang memungkinkan mereka untuk tidak hanya beradaptasi dengan perubahan tetapi juga menerima dan bahkan mencari perubahan. 
5. Gaya belajar

Keberhasilan program pengembangan dan pelatihan sumberdaya manusia dipengaruhi oleh gaya belajar. Ketika mengtakan seseorang mengatakn seseorang telah belajar, kita tidak menunjuk kepada perubahan perilaku yang bersifat sementara atau temporer. Seseorang disebut telah belajar jika pada dirinya terjadi perubahan perilaku yang bersifat menetap atau permanen.

6. Kinerja fungsi-fungsi menejemen SDM lainnya

Kinerja fungsi-fungsi manajemen SDM yakni, rekrutmen dan seleksi, pelatihan dan pengembangan, kompensasi, manajemen kinerja, perencanaan dan pengembangan karir, hubungan karyawan, manajemen PHK, dan administrasi personalia, serta sistem informasi SDM.

\section{Tujuan Umum dan Tujuan Khusus Pelatihan}

Tujuan umum dan tujuan khusus pelatihan menurut (Sedarmayanti, 2013) adalah:

1. Tujuan umum pelatihan adalah meningkatkan produktivitas organisasi, dengan melalui berbagai kegiatan antara lain :

a. Mengembangkan pengetahuan sehinggga pekerjaan dapat diselesaikan secara rasional.

b. Mengembangkan keterampilan/keahlian, sehingga pekerjaan dapat diselesaikan lebih cepat dan efektif.

c. Mengembangkan/merubah sikap, sehingga menimbulkan kemauan kerjasama dengan sesama pegawai dan manajemen (pimpinan).

2. Tujuan Khusus Pelatihan

a. Kualitas b. Produktivitas kerja

c. Mutu perencanaan tenaga kerja

d. Semangat/moral

e. Balas jasa tidak langsung

f. Kesehatan dan keselamatan kerja

g. Cegah kadaluarsa pengetahuan dan keterampilan

h. Pengembangan diri.

\section{Penilaian Kinerja}

Pada prinsipnya penilaian kinerja adalah merupakan cara pengukuran kontribusi-kontribusi dari individu dalam instansi yang dilakukan terhadap organisasi. (Riniwati, 2011) menyatakan bahwa nilai penting dalam penilaian kinerja menyangkut penentuan tingkat kontribusi individu atau kinerja yang diekspresikan dalam penyelesaian tugas yang menjadi tanggung jawabanya. Sehingga penilaiaan kinerja berguna untuk mengukur seberapa produktif seorang pegawai dan apakah ia berkinerja yang baik atau akan lebih efektif dan efisien dimasa yang akan datang sehingga pegawai dan ingkungan social sekitar mendapatkan manfaat.

Harsuko Riniwati (2011) meyatakan bahwa kinerja dapat dinilai dari kuantitas, kualitas kerja yang dihasilkan dari sumber daya manusia. Kuantitas kerja merupakan jumlah pekerjaan yang terselesaikan, sedangkan kualitas kerja yang dimaksud adalah mutu dari pekerjaan. Dessler dalam (Harsuko Riniwati, 2011), menyatakan bahwa penilaian kinerja adalah memberikan umpan balik kepada pegawai dengan tujuan memotivasi pegawai, untuk menghilangkan kemerosotan kinerja atau agar berkinerja lebih baik lagi.

Pegawai menginginkan dan memerlukan umpan balik berkenaan dengan prestasi mereka, dan penilaian menyediakan kesempatan untuk memberikan umpan balik kepada mereka. Jika kinerja tidak sesuai dengan standar, maka penilaian dapat memberikan 
kesempatan untuk meninjau kemajuan pegawai, serta menyusun rencana peningkatan kinerja.

\section{METODE PENELITIAN}

\section{Objek Penelitian}

Objek Penelitian adalah Polres Pesawaran Lampung yang berlokasi di Jl.Ahmad Yani No. 17 Kecamatan Gedong Tataan Kabupaten Pesawaran. Penelitian dilaksanakan pada bulan Agustus 2016.

\section{Metode dan Teknik Pengumpulan Data}

Dalam penelitian ini jenis data yang diperlakukan adalah :

a. Data Primer Data primer merupakan data dasar yang akan diperoleh langsung tanpa perantara orang atau lembaga lain sebagai pihak ketiga. Data primer ini diperoleh dengan wawancara melalui responden dengan menggunakan daftar pertanyaan.

b. Data Sekunder

Data skunder merupakan data yang diperoleh melalui orang lain yang berhubungan dengan permasalahan yang dipecahkan. Data sekunder ini diperoleh melalui cara studi dokumenter yaitu mengumpulkan dan mempelajari brosur-brosur serta dokumen organisasi.

Langkah-langkah pengumpulan data yang penulis lakukan dengan mengadakan penelitian lapangan, adapun teknik yang digunakan dalam pengumpulan data adalah dengan :

1. Observasi, yaitu mengadakan survey atau pengamatan langsung kelokasi penelitian.

2. Interview atau wawancara, yaitu mengadakan tanya jawab langsung.
3. Dokumentasi, yaitu mengumpulkan dan mencatat dokumentasi yang relevan.

4. Kuisioner, yaitu membuat pertanyaan yang berhubungan dengan variabel penelitian.

\section{Sampel dan Populasi}

Menurut pendapat (Suharsimi Arikunto, 2002) bahwa jika anggota populasi lebih besar dari 100 maka dapat dilakukan metode sampling dengan mengambil sampel sebesar 10 sd 25\% dari anggota populasi, tetapi jika anggota lebih kecil dari 100 sebaiknya menggunakan metode sensus dengan meneliti seluruh anggota. Dengan dasar tersebut diatas maka penelitian ini menggunakan metode sensus yaitu meneliti seluruh anggota yang berjumlah 25 orang.

\section{Metode Analisis Data}

Analisis Kualitatif yaitu pemecahan permasalahan yang dilakukan dengan cara membandingkan antara teori dengan praktek yang dilakukan pada objek penelitian.

Analisis kuantitatif yaitu menganalisis dengan menggunakan angka - angka yang dihimpun dari data perusahaan yang berkaitan dengan permasalahan yang dihadapi perusahaan.

Dalam analisis kuantitatif ini peneliti menggunakan perhitungan dengan pendekatan rumus Regresi linier Sederhana, dimana formulanya sebagai berikut:

$$
Y=a+b X+e
$$

Keterangan :

$$
\begin{aligned}
\mathrm{Y} & =\text { Kinerja } \\
\mathrm{a} & =\text { Konstanta }
\end{aligned}
$$




$$
\begin{array}{ll}
\mathrm{b} & =\text { Koefisien regresi }(\mathrm{X}) \\
\mathrm{X} & =\text { Pelatihan } \\
\mathrm{e} & =\text { error term }
\end{array}
$$

Untuk mengetahui besarnya pengaruh, penghitungan koefisien korelasi tersebut kemudian dilanjutkan dengan Rumus Koefisien Determinasi atau Koefisien Penentu (KP):

$$
K P=(r)^{2} x 100 \%
$$

Untuk menguji secara hipotesis secara parsial digunakan Uji t dengan rumus :

$$
t_{\text {hitung }}=\frac{r \sqrt{N-2}}{\sqrt{1-r^{2}}}
$$

Keterangan:

$$
\begin{array}{ll}
\mathrm{t}_{\text {hitung }} & =\text { Nilai } \mathrm{t} \\
\mathrm{r} & =\text { Koefisien Korelasi } \\
\mathrm{N} & =\text { Jumlah responden }
\end{array}
$$

Kriteria pengambilan keputusan :

1. Dengan melihat nilai signifikan (sig) sebesar 5\%. Bila nilai signifikan (sig) < 0,05 maka Ha diterima dan Ho ditolak yang bermakna model layak digunakan dalam penelitian ini, dan sebaliknya apabila nilai signifikan (sig) > 0,05 maka Ho diterima dan Ha ditolak yang bermakna model tidak layak digunakan.

2. Membandingkan nilai $t$ hasil perhitungan dengan nilai $t$ menurut tabel. Bila t hitung $>$ dari nilai $t$ tabel, maka Ho ditolak dan Ha diterima.

\section{HASIL DAN PEMBAHASAN}

\section{Uji Validitas dan Uji Realibilitas}

Uji validitas dan reliabilitas digunakan untuk pengujian instrument penelitian. Uji validitas dilakukan dalam penelitian ini untuk mengetahui valid atau tidaknya pertanyaan-pertanyaan yang digunakan dan atau dapat tidaknya digunakan sebagai alat ukur penelitian. Uji Reliabilitas digunakan untuk mengetahui nilai alpha pada setiap variabel Pelatihan (X) dan Kinerja (Y) artinya variabel ini dapat digunakan untuk penelitian jika dinyatakan reliabel bila nilai alphanya 0,396, ini berarti bahwa alat ukur yang digunakan dalam penelitian ini memiliki kemampuan untuk memberikan hasil pengukuran yang konsisten dalam mengukur gejala yang ada.

\section{Analisis Kuantitatif}

Hasil perhitungan tingkat korelasi antara variabel diperoleh besarnya tingkat korelasi antara variabel Pelatihan (X) dengan variabel Kinerja (Y) pada Polres Pesawaran Lampung Selatan adalah sebesar 0,774. Koefisien Determinasi (KD) Pelatihan $(\mathrm{X})$ terhadap Kinerja $(\mathrm{Y})$ yaitu $\mathrm{R}^{2}$ $=0,599 \times 100 \%=59,9 \%$.

Hal ini menunjukkan bahwa variabel pelatihan (X) menjelaskan perubahan terhadap variabel Kinerja (Y) sebesar $59,9 \%$, sedangkan sisanya dijelaskan oleh faktor lain yang tidak dikaji dalam penelitian ini. Standard Error of Estimate adalah suatu ukuran banyaknya kesalahan model regresi dalam memprediksikan nilai X. Dari hasil regresi didapat nilai 5,796.

Berdasarkan hasil uji $\mathrm{t}$ didapat nilai $t_{\text {hitung }}=3,460$. Apabila dibandingkan dengan $t_{\text {tabel }}(\mathrm{df}=\mathrm{n}-2)$ pada taraf signifikan yaitu 1,714, maka $\mathrm{t}_{\text {hitung }}=3,460<\mathrm{t}_{\text {tabel }}=$ 1,714 sehingga dapat disimpulkan bahwa variabel Pelatihan (X) berpengaruh terhadap Kinerja (Y).

Berdasarkan kondisi tersebut, bentuk persamaan regresinya adalah $\mathrm{Y}=10,851+$ $0,884 \mathrm{X}+$ e. Nilai koefisien pelatihan sebesar 0,884 menunjukkan apabila pelatihan meningkat sebesar 1 satuan maka kinerja juga akan meningkat sebesar 0,884 satuan. 
Dari uji ANOVA atau $\mathrm{F}$ test didapat $\mathrm{F}$ hitung sebesar 11,972 dengan tingkat signifikan 0,009 karena probability lebih kecil dari 0,05, maka pelatihan (X) berpengaruh secara simultan terhadap kinerja (Y) pada Polres Pesawaran Lampung Selatan.

Berdasarkan penelitian yang telah dilakukan, dapat diketahui bahwa pelatihan berpengaruh secara signifikan terhaadap kinerja penyidik pembantu pada Polres Pesawaran Lampung Selatan. Dengan mengikuti pelatihan maka penyidik pembantu akan lebih paham dalam menangani berkas dan mengasah kemampuan penyidik pembantu pada Polres Pesawaran Lampung Selatan.

\section{KESIMPULAN DAN SARAN}

\section{Kesimpulan}

Berdasarkan analisis data dan pembahasan dapat disimpulkan bahwa pelatihan (X) pada Polres Pesawaran Lampung Selatan dalam kategori baik. Untuk perhitungan koefisien determinasi menunjukkan bahwa persentase sumbangan perubahan variabel independen pelatihan (X) terhadap variabel dependen kinerja (Y) sebesar $59,9 \%$ dan sisanya dipengaruhi faktor lain. Uji hipotesis parsial melalui uji $\mathrm{t}$ test diperoleh nilai $\mathrm{t}$ hitung pelatihan terhadap kinerja sebesar 3,460 dan $t_{\text {hitung }}=$ $3,460>t_{\text {tabel }}$ 1,714. Persamaan regresi antara pelatihan dan kinerja pada Polres Pesawaran Lampung Selatan adalah sebesar $\mathrm{Y}=10,851+0,884 \mathrm{X}+\mathrm{e}$, yang menunjukkan setiap kenaikan satu satuan dari variabel pelatihan akan diikuti oleh naiknya variabel kinerja sebesar 0,884 satuan. Berdasarkan uji $\mathrm{F}$ didapat $\mathrm{F}$ hitung sebesar 11,972 dengan tingkat signifikan 0,009 karena probability lebih kecil dari 0,05, maka pelatihan (X) berpengaruh secara simultan terhadap kinerja (Y) pada Polres Pesawaran Lampung Selatan.

\section{Saran}

Berdasarkan hasil penelitian diatas, saran yang dapat disampaikan adalah:

1. Pelatihan belum sepenuhnya mendidik/membimbing para penyidik pembantu sebaiknya dalam pelatihan dapat dijelaskan/membimbing dengan benar para penyidik pembantu dalam menegerjakan tugasnya.

2. Masih adanya beberapa penyidik yang belum sepenuhnya mampu menyelesaikan berkas yang mereka tangani, sebaiknya penyidik pembantu bisa bertanya atau meminta bantuan dan bimbingan dari senior dalam menangani kasus/masalah.

\section{DAFTAR PUSTAKA}

Arikunto, Suharsimi. 2002. Prosedur Penelitian, Ed Revisi V. Jakarta: Rineka Cipta.

Harbani, Pasolong. 2013. Manajemen Sumber Daya Manusia, Reformasi Birokrasi. Bandung: Alfabeta.

Hasibuan, Malayu SP. 2008. Manajaemen Sumber Daya Manusia. Cetakan ke11. Jakarta: Bumi Aksara.

Mahsun, Mohamad. 2006. Pengukuran Kinerja Sektor Publik. Yogyakarta: BPFE.

Mangkunegara, Anwar Prabu. 2011. Manajemen Sumber Daya Manusia Perusahaan. Bandung: Rosda.

Marwansyah. 2014. Manajemen Sumber Daya Manusia. Jakarta: Alfabeta.

Riniwati, Harsuko. 2011. Mendongkrak Motivasi dan Kinerja: Pendekatan 
Pemberdayaan SDM. Malang: UB Press.

Sedarmayanti. 2009. Sumber Daya Manusia dan Produktivitas Kerja. Jakarta: CV. Mandar Maju.

Sinambela, Lijan Poltak. 2012. Kinerja Pegawai. Yogyakarta: Graha Ilmu.

Sugiyono 2007. Statistika Untuk Penelitian. Bandung: Alfabeta.

Sutrisno, Edy. 2009. Manajemen Sumber Daya Manusia. Jakarta: Kencana. 